\title{
PENGALAMAN IBU MERAWAT ANAK DENGAN TUNAGRAHITA DI BANDAR LAMPUNG
}

\author{
Marliyana \\ Akademi Keperawatan Baitul Hikmah Bandar Lampung \\ Email: marliyana.nafa@yahoo.com
}

\begin{abstract}
Mother's Experiences in Caring for a Mental Retardation Children in Bandar Lampung. Mental retardation is a condition that intelegency has significant below average and accompanied by incompetence in the adaptation behavior that appeared in the development. Sometimes, parents who has a mental retardation children didn't concern with their growth and developments factors. This study was to explore the mother's experiences in caring for children with mental retardation in Bandar Lampung. It was the qualitative study with the phenomenology approach. Respondent were the mother who has children with mental retardation, total number were 6 peoples. Data were collected by indepth interview. Data were analyzed using thematic analysis according to Collaizz methode. The results showed that there were six theme: 1) mother's Response who has a mental retardation children, 2) caring a mental retardation children, 3) family's treatment in caring for a children mental retardation, 4) kinds of family support, 5) spiritual message to family who has mental retardation children, 6) family's hope who has a mental retardation children.
\end{abstract}

Keywords: Children mental retardation, Mother's experiences

\begin{abstract}
Abstrak: Pengalaman Ibu Merawat Anak dengan Tunagrahitadi Bandar Lampung. Tunagrahita adalah kondisi dengan intelengsi yang signifikan berada dibawah rata-rata dan disertai dengan ketidakmampuan dalam adaptasi perilaku yang muncul dalam masa perkembangan. Perlakuan orang tua dengan anak tunagrahita seringkali tidak memperhatikan faktor pertumbuhan dan perkembangananak tunagrahita. Penelitian ini bertujuan mengekspolrasi secara mendalam pengalaman ibu merawat anak dengan tungrahita di Bandar Lampung.Penelitian ini merupakan penelitian kualitatif dengan pendekatan fenomenologi. Partisipan pada penelitian ini adalah ibu yang memiliki anak dengan tunagrahita dengan jumlah 6 orang. Pengumpulan data dengan caraindepth interview. Analisa data menggunakan analisa tematik menurut Collaizz's methode. Hasil penelitian terdapat enam tema yaitu 1) Respon ibu memiliki anak tunagrahita, 2) mengasuh anak tunagrahita, 3) usaha keluarga mengasuh anak dengan tunagrahita,4) jenis dukungan keluarga dengan anak tunagrahita, 5) hikmah spiritual keluarga dengan anak tunagrahita, 6) harapan keluarga dengan anak tunagrahita. Berdasarkan hasil penelitian direkomendasikan bahwa keluarga dengan anak tunagrahita perlu bergabung dalam self help group. Perawat anak dapat membentuk Self Help Group bagi keluarga dengan anak tunagrahita. Bagi peneliti selanjutnya dapat meneliti tentang spiritual keluarga dan pengaruhnya pada anak dengan tunagrahita.
\end{abstract}

Kata kunci: Anak tunagrahita, Merawat, Pengalaman ibu

Pengalaman peneliti pernah melihat ibu M yang berusia 48 tahun yang memiliki anak tunagrahita. Anak ibu M laki-laki berusia 9 tahun. Ibu M sedang memarahi anaknya dengan nada tinggi dan kasar. Ekspresi wajah ibu tampak sangat marah. Bahkan Ibu $M$ mengancam anaknya akan dikurung. Kemarahan ibu M dipicu karena anaknya meminta sesuatu tetapi ibu keberatan untuk membelikannya. Saat anaknya menangis ibu $\mathrm{M}$ tidak berusaha mendiamkan tetapi malah tambah marah.

Hasil observasi terlihat ibu dengan sabar merawat dan memenuhi kebutuhan sehari-hari anaknya, mengupayakan anaknya bisa sekolah di Sekolah Luar Biasa (SLB), ibu selalu mengantar dan menunggu anaknya sampai waktu pulang sekolah. Peneliti juga melakukan wawancara pada ibu S, pada tanggal 26 Desember 2014, Ibu S mengatakan :

"Bahwa pengalaman yang membutuhkan kesabaran merawat anak dengan tunagrahita. Awalnya saya sedih dan tidak percaya melihat anak saya berbeda dengan anak-anak yang lainnya, sekolah di SD biasa tidak bisa mengikuti, makanya saya sekolahkan di SLB biar tetap bisa baca tulis lah.Belum lagi omongan tetangga bikin telinga saya sakit. Kadang kalau main jadi bahan ejekan sama teman-temannya. Ujian ini sangat berat buat kami, tapi saya selalu berdoa pada Allah agar saya dan keluarga diberi kesabaran". Saya dan keluarga berusaha supaya 
anak saya bisa mandiri, sekolah, dan memiliki ketrampilan untuk bekal hidupnya kelak".

Studi pendahuluan di wilayah kota Bandar Lampung, data anak dengan tunagrahita yang tercatat di Sekolah Luar Biasa (SLB) Di Bandar Lampung berjumlah 96 anak, dengan kriteria tunagrahita ringan dan sedang. Pada sekolah tersebut belum melibatkan tenaga kesehatan khususnya perawat untuk memberikan pelayanan kesehatan pada anak tunagrahita. Dukungan dari masyarakat dan pemerintah pada anak dan keluarga tunagrahita belum ada, hal ini terlihat dengan belum adanya kelompok swabantu, sarana khusus.

Tunagrahita merupakan keterbatasan subtansial dalam memfungsikan diri. Keterbatasan ini ditandai dengan terbatasnya kemampuan fungsi kecerdasan di bawah rata-rata (IQ 70 atau kurang).Kondisi ini ditandai dengan terbatasnya kemampuan tingkah laku adaptif minimal di dua area atau lebih (Wibowo, 2009; Hockenberry, 2009).

Menurut Somantri (2007), orang yang paling banyak menanggung beban akibat tunagrahita adalah orangtua dan keluarga anak tersebut. Tunagrahita berdampak bagi orangtua seperti perasaan bersalah, berdosa, kurang percaya diri, tidak percaya, malu dan over protective.

Penelitian Shabo (2011), menunjukkan bahwa orang tua ketika mengetahui anaknya mengalami tunagrahita mengalami masalah psikologis yang berbeda. Namun mereka cenderung untuk mengatasi masalah dan menyesuaikan dengan situasi, walaupun kadangkadang, timbul masalah dalam kehidupan perkawinan dan lingkungan sosial. Penelitian ini menunjukkan bahwa sebagian besar orang tua menderita kecemasan dan depresi mulai dari berat sampai sedang. Namun jumlah, usia anakanak tidak mempengaruhi secara signifikan secara sosial dan psikologis orang tua. Pemberian dukungan pada keluarga untuk mengurangi dampak secara psikologis dan sosial melalui penyediaan layanan rehabilitasi dan pelatihan bagi anak-anak di sekolah dan lembaga khusus untuk anak tunagrahita.

Penelitian ini bertujuan untuk mengeksplorasi secara mendalam pengalaman ibu merawat anak dengan tunagrahita di Bandar Lampung.

\section{METODE PENELITIAN}

Desain penelitian ini menggunakan metode penelitian kualitatif dengan pendekatan fenomenologi deskriptif.

Sampel dalam penelitian kualitatif disebut dengan partisipan. Teknik sampling yang digunakan dalam pemilihan partisipan dalam penelitian ini menggunakan teknik purposive, dimana partisipan yang dipilih sesuai dengan kriteria dan tujuan penelitian. Pada penelitian ini saturasi data peneliti dapatkan pada partisipan yang keenam, sehingga jumlah partisipan pada penelitian ini berjumlah 6 ibu dengan anak tunagrahita.

Prosedur pengumpulan data terdiri dari :

1. Tahap Persiapan: Tahap persiapan peneliti melakukan pertemuan dengan calon partisipan sesuai dengan kriteria penelitian. Selanjutnya peneliti melakukan interaksi dengan membina hubungan saling percaya dengan calon partisipan. Peneliti menjelaskan tentang tujuan penelitian, manfaat penelitan, prosedur penelitian, batasan keterlibatan partisipan, hak dan kewajiban serta jaminan hak-hak partisipan.apabila calon partisipan bersedia secara suka rela untuk menjadi partisipan penelitian, peneliti meminta partisipan untuk mengisi dan menandatangani pernyataan kesediaan mengikuti penelitian. Penelitimembuat kesepakatan waktu dan tempat untuk wawancara mendalam dengan partisipan.

2. Tahap Pelaksanaan: Pada tahap pelaksanaan peneliti melakukan wawancara dalam tiga fase, yaitu: Fase Orientasi memperhatikan kondisi partisipan secara fisik maupun psikologis. Bentuk perhatian ditunjukan dengan menanyakan kondisi kesehatan yang bertujuan mengidentifikasi kesiapan partisipan untuk diwawancarai (Alwasilah, 2006). Peneliti memberikan lembar informed consent pada partisipan untuk berpartisipasi dalam penelitian. Jika partisipan bersedia berpartisipasi dalam penelitian maka peneliti dan partisipan membuat kontrak mengenai waktu dan tempat dilaksanakannya wawancara.

Validasi dan persepsi mengenai kontrak waktu peneliti lakukan terhadap partisipan. Peneliti menanyakan kesiapan partisipan untuk diwawancara karena dengan kesiapan partisipan akan mempengaruhi hasil wawancara. Peneliti berusaha menciptakan suasana lingkungan yang nyaman dengan duduk berhadapan dan di tempat yang telah disepakati. Peneliti menjaga privacy 
partisipan selama wawancara berlangsung. Peneliti menyiapkan perekam wawancara, menyiapkan alat tulis dan catatan lapangan untuk mengidentifikasi bahasa non verbal partisipan selama wawancara. Sebelum wawancara dimulai, peneliti juga mengidentifikasi posisi alat perekam yang tepat agar dapat merekam semua percakapan selama wawancara dengan baik dan jelas, yaitu voice recorder diletakan di antara peneliti dan partisipan dengan jarak kurang lebih $50 \mathrm{~cm}$. Hal ini dilakukan dengan tujuan agar suara peneliti dan partisipan dapat terekam dengan jelas.

3. Fase Kerja: Fase kerja dimulai dengan wawancara mendalam kepada partisipan dimana peneliti mengawali dengan pertanyaan "Ibu bisa ceritakan kepada saya tentang bagaimana pengalaman ibu merawat anak dengan tunagrahita?", pada saat wawancarasaat pembicaraan partisipan keluar dari tema yang akan dibicarakan, peneliti memfokuskan partisipan pada tema pembicaraan yang sedang dibahas. Peneliti mengembangkan pertanyaan tersebut berdasarkan jawaban dari partisipan, sehingga peneliti dapat menggali lebih dalam pengalaman partisipan. Peneliti menggunakan bahasa yang mudah dimengerti oleh partisipan dan melakukan klarifikasi terhadap jawaban partisipan yang belum jelas.

Peneliti memperhatikan respon non verbal partisipan dan kesesuaiannya dengan respon verbal. Hasil respon non verbal dicatat pada catatan lapangan. Catatan lapangan digunakan oleh peneliti untuk menggambarkan suasana saat dilakukan wawancara, mimik wajah, perilaku dan respon non verbal partisipan selama wawancara berlangsung. Catatan lapangan disusun dalam panduan catatan lapangan yang menggambarkan respon partisipan selama wawancara berlangsung.

4. Fase Terminasi: Terminasi dilakukan setelah semua data lengkap dan kedalaman data sesuai tujuan penelitian. Peneliti menutup wawancara dengan mengucapkan terima kasih atas partisipasi dan kerjasama partisipan selama wawancara. Peneliti kemudian membuat kontrak kembali dengan partisipan untuk pertemuan selanjutnya yaitu untuk validasi data. Peneliti melakukan tahap terminasi pada saat semua partisipan sudah divalidasi terhadap hasil transkip wawancara. Peneliti memberikan hasil verbatim dan rekaman wawancara kepada partisipan untuk disesuaikan.

Peneliti menanyakan kesesuaian antara hasil rekaman dengan fakta yang dialami oleh partisipan. Peneliti mengucapkan terima kasih atas partisipasi dan kerjasama kepada partisipan dan mengatakan proses penelitian sudah selesai.

Analisis data dilakukan menggunakan metode Colaizzi (Sanders, 2003) yang terbagi dalam langkah-langkah sebagai berikut ini :

1. Tahap 1: Acquiring a Sense of Each Transcript

Colaizzi (Sanders, 2003) menganjurkan bahwa peneliti harus membaca transkrip partisipan untuk mendapatkan perasaan, ideide, dan memahami partisipan.Menurut Haase dan Myers (Sanders, 2003) menyarankan untuk mendengarkan hasil rekaman beberapa kali. Untuk mendapatkan perasaan dari setiap transkrip pengalaman orang tua dengan anak tunagrahita, peneliti awalnya mendengarkan setiap rekaman berulang-ulang dan membaca setiap transrip berulang-ulang. Selanjutnya peneliti meminta partisipan untuk memvalidasi pengalaman mereka. Setelah dilakukan validasi pengalaman partisipan, tidak ada yang ditambahkan atau dihilangkan.

2. Tahap 2: Extracting Significant Statements Langkah selanjutnya peneliti membaca kembali transkrip secara berulang-ulang untuk menggali pernyataan yang signifikan. Peneliti memilih pernyataan yang signifikan, kemudian dipilih pernyataan yang bermakna dari pengalaman ibu selama merawat anak tunagrahita. Peneliti menganalisis setiap transkrip untuk mengidentifikasi pernyataan yang menceritakan kisah dari setiapmasingmasing partisipan. Pernyataan-pernyataan tersebut diwarnai pada setiap halaman dari setiap transkrip menggunakan stabilo.

3. Tahap 3: Formulating of Meanings

Peneliti selanjutnya mengartikulasi makna dari setiap pernyataan yang signifikan, selanjutnya peneliti menyimak kembali dengan membaca tiap-tiap pernyataan tersebut. Pada tahap ini peneliti dapat membentuk beberapa developing meaning dari beberapa pernyataan signifikan yang ada.

4. Tahap 4: Organizing Formulated Meanings into clusters of themes

Setelah merumuskan makna, kemudian peneliti mengelompokan makna-makna kedalam kelompok tema dengan menyusun 
tabel kisi-kisi tema yang memuat pengelompokan developing meaning kedalam sub tema, dan tema.

5. Tahap 5: Exhaustively describing the investigated phenomenon

Menuliskan deskripsi secara lengkap dan mendalam. Pada tahap ini peneliti telah mendeskripsikan tiap-tiap tema yang muncul sebagaihasil temuan penelitian terkait pengalaman orang tua dengan anak tunagrahita. Deskripsi hasil penelitian ini dituangkan dalam penulisan hasil penelitian.

6. Tahap 6: Describing the fundamental structure of the phenomenon.

Haase dan Myers (Sanders, 2003) menyebutkan bahwa menggambarkan struktur dasar dari setiap fenomena harus mencangkup penjelasan tentang proses dan makna yang melalui langkah-langkah analisis sebelumnya. Dengan menggambarkan struktur, pembaca mendapatkan gambaran dari fenomena partisipan, dapat merasakan menilai dan memaknainya dari makna, tema yang terkandung di dalam pengalaman orang tua merawat anak dengan tunagrahita.

7. Tahap 7: Returning to the Participants

Pada penelitian ini, peneliti memvalidasi kembali gambaran pengalaman partisipan tersebut dengan mengunjungi kembali pada keseluruhan partisipan.

\section{HASIL}

Hasil analisa tematik dengan 6 partisipan diperoleh 6 tema. Tema tersebut yaitu:

1. Respon ibu memiliki anak tunagrahita.

Respon ibu dengan anak tunagrahita menunjukkan kesedihan yang mendalam. seorang ibu yang mempunyai anak dengan tunagrahita akan mengalami kesedihan. Respon sedih ibu didukung oleh tiga kategori antara lain: sedih, bingung dan pasrah. Partisipan merasa sedih karena anaknya tidak dapat diperlakukan sama dengan anak lainnya, sedih ditunjukkan dengan ibu menangis seharian karena mengetahui anaknya mengalami tunagrahita. Partisipan yang lain mengungkapkan sedih karena anaknya cacat. Hasil wawancara mendalam dengan enam partisipan, hampir semua partisipan mengatakan sedih saat mengetahui anaknya mengalami tunagrahita. Partisipan satu merasa sedih karena anaknya berbeda dari anak lainnya, yang tidak bisa diperlakukan dengan kasar. Dua orang partisipan mengungkapkan sedih karena anaknya kok cacat, Partisipan ketiga merasa sedih karena sebagai manusia normal perasaan hancur itu ada.

2. Mengasuh anak dengan tunagrahita.

Penelitian ini mendapatkan temuan mengasuh anak dengan tunagrahita, tidak mengalami perubahan. beberapa partisipan mengungkapkan bahwa mengasuh anak dengan tunagrahita tidak ada perubahan. Hal ini tertuang dalam ungkapan mengurus anak tunagrahita seperti biasa saja, tidak ada bedanya dengan anak pada umumnya. Partisipan lain mengungkapkan perubahan yang terjadi selama mengasuh anak tunagrahita dengan perhatian yang lebih. Perhatian yang lebih diungkapkan ibu dalam bentuk memberikan apa yang semua yang diinginkan oleh anaknya.

Partisipan juga ada yang mengungkapkan rasa khawatir pada anak tunagrahita. Rasa khawatir ibu berupa ungkapan, ibu tidak bisa meninggalkan pergi pada acara keluarga apalagi sampai bermalam.

Ungkapan lain juga ibu merasa khawatir saat anaknya bermain keluar rumah, khawatir bila teman-temannya nakal. Partisipan lain ada mengungkapkan mengasuh anak tunagrahita dibawa enak saja dan tidak dijadikan beban, dibawa enak saja ini diungkapkan partisipan dalam bentuk mengasuh dengan ikhlas dan menerima anak tunagrahita.

3. Usaha keluarga mengasuh anak tunagrahita.

Usaha keluarga mengasuh anak tunagrahita menunjukkan perhatian dan kasih sayang orang tua pada anaknya. Hampir semua partisipan mengungkapan bahwa anak tunagrahita tetap harus disekolahkan dengan tujuan memandirikan anak, bergaul dengan teman-temannya, mampu membaca dan menulis. Sebagian partisipan juga mengungkapkan selain disekolahkan anaknya perlu diberikan latihan untuk memandirikan, ini terlihat dari bagaimana orang tua melatih kemampuan pemenuhan kebutuhan seharihari anak. Empat orang partisipan juga mengupayakan pengobatan bagi anak tunagrahita baik ke dokter, rumah sakit dan ke alternatif. Salah satu partisipan mengungkapkan bahwa anaknya dibawa ke dokter anak, dokter psikiatri khusus anak, membawa urut sampai 4 tahun lamanya, dan memberikan obat-obat herbal.

4. Jenis dukungan keluarga dengan anak tunagrahita.

Jenis dukungan keluarga dengan anak tunagrahita menunjukkan penerimaan keluarga akan keberadan anak tunagrahita. 
Temuan ini berdasarkan ungkapan partisipan yang mendapatkan dukungan dari anggota keluarga inti dan keluarga yang lainnya. Partisipan mengungkapkan bahwa mereka selalu dinasehati oleh keluarga untuk selalu bersabar. Nasehat yang didapatkan partisipan berasal dari orang suami, orang tua, kakak/adik/ipar, dan keluarga yang lain. Keluarga memotivasi ibu untuk tetap menyekolahkan anaknya. beberapa partisipan juga mendapatkan bantuan biaya pengobatan bagi anak tunagrahita.

5. Hikmah spiritual keluarga dengan anak tunagrahita.

Hikmah spiritual keluarga dengan anak tunagrahita menunjukkan keimanan keluarga. Keimanan keluarga ini tertuang dalam ungkapan beberapa partisipan berupa sikap sabar. Tetap bersyukur dengan adanya anak tunagrahita di dalam keluarga. Sabar diungkapkan partisipan dengan diberikan anak tunagrahita alhamdulilah jadi melatih kesabaran saya. Partisipan mengungkapkan kesabaran ganda yang harus dimiliki oleh orang tua dengan anak tunagrahita. Partisipan lain mengungkapkan tidak semua orang bisa memiliki anak seperti ini. Allah memberikan anak seperti ini pada saya berarti kami dipercaya untuk merawatnya. partisipan mengungkapkan tetap bersyukur dengan memilki anak tunagrahita. Rasa syukur diungkapkan partisipan dalam bentuk memperbanyak ibadah sholat, mulai dari sholat tahajut, hajat dan banyak berdoa untuk kesehatan anaknya. Salah satu partisipan mengungkapkan bahwa tadinya belum memakai jilbab setelah memilki anak tunagrahita jadi menggunakan jilbab. Hasil wawancara mendalam dengan partisipan, dua orang partisipan mengatakan hikmah merawat anak dengan tunagrhita melatih kesabaran. Sabar tertuang dalam bentuk ungkapan harus banyak bersabar, menghadapi anak seperti ini harus memiliki kesabaran ganda.

Hasil wawancara mendalam dengan partisipan, didapatkan hampir seluruh partisipan mengatakan bersyukur dianugrahi anak dengan tunagrahita. Rasa syukur partisipan ini ditunjukkan dengan ungkapan alhamdulillah sudah dikasih anak seperti ini berarti saya di beri kepercayaan oleh Allah SWT. Ada Partisipan yang mengungkapkan bahwa dengan memiliki anak tunagrahita mereka mendapatkan rejeki yang lebih banyak.

Sebagian partisipan mengatakan dengan memiliki anak tunagrahita menjadi lebig tawakal. Tawakal ini ditunjukkan dengan perilaku berserah diri pada Allah SWT, lebih banyak melakukan ibadah seperti sholat, mengaji.

6. Harapan keluarga dengan anak tunagrahita.

Harapan keluarga dengan anak tunagrahita menunjukkan perhatian yang besar pada anak tunagrahita.

Harapan ini terungkap dari pernyataan partisipan yang menginginkan anaknya di prioritaskan saat memberikan pelayanan kesehatan. ungkapan ini dinyatakan partisipan bahwa anak dengan anak tunagrahita tidak dapat menunggu terlalu lama, bila terlalu lama dia bisa saja marah dengan barang atau anak lain yang didekatnya. Partisipan juga mengharapkan tenaga kesehatan dapat memberikan pelayanan dengan sabar dan baik pada anak tunagrahita. Partisipan lain juga mengungkapkan adanya pelayanan yang khusus untuk anak tunagrahita dan terjangkau dalam hal biaya.

Berdasarkan wawancara dengan enam partisipan, sebagian menyampaikan harapannya untuk pelayanan kesehatan anak tunagrahita lebih diutamakan dari yang lainnya.

Partisipan ada yang mengungkapkan harapannya pada pelayanan kesehatan, untuk melayani anak tunagrahita dengan penuh kesabara, memberikan pelayanan baik, dan tidak mahal. Mereka berharap pelayanan pemerintah menyediakan pelayanan kesehatan khusus untuk anak tunagrahita yang terjangkau dari segi biaya.

\section{PEMBAHASAN}

Perasaan sedih ibu dengan memiliki anak tunagrahita ditunjukkan dengan reaksi ibu menangis terus menerus, tidak bisa tidur dan menyalahkan yang maha kuasa. Perasaan sedih ibu dengan anak tunagrahita mungkinterjadi karena ibu mengalami kecemasan. Kecemasan ibu mungkin diakibatkan karena memikirkan mengapa memiliki anak yang berbeda dengan anak yang lainnya, sedih karena memiliki anak seperti ini.Hal ini sejalan dengan hasil penelitian Muhammad, et al. (2013), bahwa ibu dengan anak tunagrahita mengalami kecemasan. kecemasan ibu disebabkan karena tingkat ketergantungan yang tinggi anak tunagrahita pada orang lain. Penelitian lain menurut Dave, Mittal, Tiwari, Parmar, Gedan, dan Patel (2014) bahwa keluarga yang memiliki anak tunagrahita mengalami kecemasan. Kecemasan keluarga 
dikaitkan dengan jenis kelamin, agama, pendidikan, status perkawinan dan usia.

Ungkapan partisipan pada penelitian ini, bahwa ada rasa khawatir saat harus meninggalkan anak sendiri. Rasa khawatir orang tua pada anak tunagrahita mungkin diakibatkan karena anak tunagrahita tidak mampu untuk melindungi diri sendiri. Hal ini diperkuat dengan pendapat Saragih (2011) bahwa dalam keluarga dengan anak tunagrahita memperoleh perlakuan yang berbeda dari orang tua, berupa perlindungan dan kasih sayang yang berlebihan.

Perlakuan tersebut diberikan oleh orang tua sebagai akibat kekhawatiran orang tua terhadap keberadaan anak tunagrahita, dimana mereka dianggap tidak mampu untuk menjaga diri sendiri. Upaya keluarga untuk menyekolahkan anak dengan tunagrahita dengan harapan mungkin anaknya dapat berlatih untuk mandiri, belajar tentang aturan dalam kehidupan sehari-hari. Perlakuan ibu sebagai pengasuh dirumah mungkin akan dapat membentuk kebiasaan dan mengetahui sesuatu hal yang boleh dan tidak dilakukan. Hal ini sejalan dengan pendapat kosasih (2012) bahwa penanganan yang perlu diberikan pada anak tunagrahita lebih difokuskan kepada life skill dan kemampuan merawat diri. Kemampuan mengurus diri sendiri pada anak tunagrahita mungkin bisa didapatkan selain dirumah juga disekolah luar biasa. Hal ini sejalan dengan pendapat Soetjiningsih (2014) bahwa anak dengan tunagrahita memerlukan pendidikan khusus, yang disesuaikan dengan taraf IQ nya.Mereka digolongkan yang mampu didik dan yang mampu latih. Pada sekolah ini diajarkan kertampilan-ketrampilan dengan harapan mereka dapat mandiri di kemudian hari.

Dukungan keluarga mungkin merupakan suatu upaya yang diberikan dari anggota keluarga yang lain, dalam hubungannya antara keluarga. Hal ini sejalan dengan pendapat Riza (2012) bahwa dukungan yang diberikan pada keluarga dengan anak tunagrahita berupa dukungan baik moril maupun materil.

Partisipan mengungkapkan bahwa mereka mendapatkan dukungan dari orang tua, dan keluarga dengan berbagai jenis dukungan. Berbagai jenis dukungan yang didapatkan ibu selama mengasuh anak dengan tunagrahita mungkin dapat membuat ibu merasa ada yang membantu, ibu tidak sendiri, dan ada yang memberikan motivasi. Hal ini dilakukan dengan harapan beban yang ditanggung ibu dapat berkurang hal ini sejalan dengan pendapat Freidman (2010) bahwa jenis dukungan keluarga terdiri dari dukungan instrumental berupa pertolongan praktis, dukungan informasi dengan memberikan informasi terkait merawat anak tunagrahita, dukungan penilaian berupa umpan balik terhadap apa yang sudah dilakukan orang tua pada anaknya, dukungan emosional berupa penguatan orang tua, dukungan finansial berupa bantuan biaya untuk perawatan, dandukungan spiritual dengan cara mendoakan kesehatan anak dengan tunagrahita.

Dukungan dari tenaga kesehatan diantaranya perawat, khususnya perawat spesialis anak, mungkin dapat membantu keluarga tentang cara merawat anak dengan tunagrahita. Dukungan yang diberikan dapat berupa membentuk kelompok swabantu bagi keluarga dengan anak tunagrahita. Kelompok ini mungkin akan sangat berguna bagi keluarga saling berbagi pengalaman merawat, dan strategi yang tepat memandirikan anak tunagrahita.

Beberapa partisipan juga mengungkapkan bahwa menjalani hidup dengan anak tunagrahita tidak terlalu dijadikan beban sehingga bisa menjalani dengan nyaman. Menjalani hidup dengan anak tunagrahita tidak menjadi beban mungkin saja karena ibu sudah mengetahui dan mampu mengasuh anak tunagrahita dengan baik.

Ungkapan partisipan berbeda dengan hasil penelitian Fairthorne, Fisher, Bourke, dan Leonard (2014) bahwa pengalaman yang berdampak pada kualitas hidup ibu dengan anak tunagrahita. Hidup dengan anak yang mengalami kecacatan dengan ciri khusus, ibu harus mampu beradaptasi dengan gaya hidup baru, bertahan terhadap tantangan dan menikmati apa yang ada.

Hikmah spiritual keluarga dengan anak tunagrahita digambarkan dalam hasil penelitian sabar, bersyukur, dan tawakal. Sebagian partisipan mengungkapkan bahwa memilikii anak dengan tunagrahita dapat melatih kesabaran. Partisipan lainnnya mengungkapkan mereka bersyukur karena diberikan kepercayaan mengasuh anak dengan tunagrahita. Ada juga partsipan yang mengatakan bahwa dengan adanya anak tunagrahita keluarga menjadi lebih dekat dengan yang maha pencipta.

Memiliki anak tunagrahita membuat keluarga lebih banyak beribadah dengan cara banyak sholat, berdoa. Hal ini sejalan dengan pendapat Alisyahbana (2012), bahwa mendidik anak dengan tunagrahita memerlukan kesabaran, ketelatenan yang luar biasa dan kasih sayang tanpa syarat (unconditional love). Untuk mencapai kesabaran, rasa syukur, dan bertawakal diperlukan spiritual yang baik.

Menurut Kozier (2010) Spiritualitas merupakan kekuatan yang menyatukan, memberi makna kebutuhan akan makna, tujuan, cinta, keterikatan, dan pengampunan pada kehidupan 
dan nilai-nilai individu, persepsi, kepercayaan dan keterikatan di antara individu.Spiritual keluarga menjadi kebutuhan dasar keluarga selama mereka mengurus anak dengan tunagrahita. Hal ini sejalan dengan pendapat Kontjaraningrat (2010) bahwa aspek spiritual yang begitu kuat pada keluarga terimplikasi pada perilaku dan pola berpikir keluarga, sehingga segala sesuatu yang terjadi diluar kemampuan dan kendalinya akan diserahkan kepada Tuhan Yang Maha Kuasa.

Harapan keluarga mungkin merupakan hal yang wajar, mengingat bahwa anak tunagrahita juga berhak mendapatkan pelayanan kesehatan seperti anak yang lainnya. Kondisi anak tunagrahita yang membutuhkan perhatian khusus dari tenaga kesehatan. Menurut Soetjiningsih (2014) bahwa semua anak yang mengalami tunagrahita memerlukan perawatan seperti pemeriksaan kesehatan secara rurin, imunisasi, monitoring tumbuh kembangnya. Terwujudnya perkembangan dan kesehatan anak tunagrahita memerlukan kerjasama yang baik antara pemerintah, pelayanan kesehatan dan pihak pendidikan anak di sekolah luar biasa melalui Usaha Kesehatan Sekolah (UKS).

\section{SIMPULAN}

Respon ibu ketika mengetahui anaknya mengalami tunagrahita menunjukkan perasaan sedih, bingung dan pasrah. Mengasuh anak dengan tunagrahita menimbulkan perasaan khawatir, perhatian yang lebih, dan ibu tetap dapat menjalani hidup seperti biasa. Usaha keluarga mengurus anak tunagrahita dilakukan dengan cara memberikan pendidikan khusus seperti Sekolah Luar Biasa (SLB), melatih kemandirian. Jenis dukungan keluarga dengan anak tunagrahita, berupa dukungan moril dan material. Hikmah spiritual keluarga dengan anak tunagrahita adalah sikap sabar, bersyukur dan tawakal kepada Allah SWT.Harapan keluarga dengan anak tunagrahita adalah diprioritaskan, sikap petugas kesehatan yang sabar, memberikan pelayanan dengan baik.

\section{SARAN}

Orang tua dengan anak tunagrahita sebaiknya dapat bergabung dengan Self help group untuk dapat berbagi pengalaman merawat anak dengan tunagrahita. Perawat anak sebaiknya dapat membentuk Self help group bagi keluarga dengan anak tunagrahita. Institusi pendidikan anak tunagrahita adanya kerjasama lintas sekotoral antara kementrian pendidikan dan kementrian kesehatan sehingga pada institusi pendidikan luar biasa terdapat pelayanan kesehatan bagi anak tunagrahita, Penelitian selanjutnya dapat meneliti terkait pengalaman spiritual keluarga yang memiliki anak dengan tunagrahita.

\section{DAFTAR PUSTAKA}

Alisyahbana. 2012. Kuantar ke Cakrawala: Menjadikan Tunagrahita Bagian dari Masyarakat Inklusif. Jakarta: Jala Permata.

Alwasilah. 2006. Dasar-dasar Merancang dan Melakukan Penelitian Kualitatif. Jakarta: Pustaka Jaya.

Dave, Mittal, Tiwari, Parmar, Gedan, dan Patel.2014. Study of Anxiety and Depression in Caregivers of Intellectually Disabled Children. Journal of Research in Medical and Dental Science, 2(1) 9-13.

Fairthorne.,J, Fisher.,C, Bourke., J dan Leonardat., H. 2014. Experience Impacting The Quality of Life of Mother of Children with Autis and Intellectual Disability. Psychology Research,4(8),666-684.

Freidman,M.M, Bowden. V.R.,Jones, E.G. 2010. Family Nursing: Theory and Assesment. $5^{\text {th }}$ Ed.Conectious: Apleton Century Cropts.
Gralfitrisia. 2012. Dukungan Keluarga dalam Merawat Anak Tunagrahita. http://repository.usu.ac.id (Diakses tanggal 5 Februari 2015).

Koentjaraningrat. 2010. Manusia dan Kebudayaan di Indonesia. Jakarta: Penerbit Djambatan.

Kosasih. 2012. Cara Bijak Memahami Anak Berkebutuhan Khusus. Bandung: Yrama Widya.

Kozier, Erb, Berman, Snyder. 2010. Buku Ajar Fundamental Keperawatan (Ed.7 Vol.2). Jakarta: EGC.

Muhammad, et all. 2013. Anxiety and Depression among Parents of Children with Intellectual Disability In Pakistan. J Can Acad Child Adolesc Psychiatry, 22:4, 290295.

Riza. 2012. Dukungan Keluarga Dalam Hospitalisasi Anak Usia Pra Sekolah Di 
Rumah Sakit Umum Daerah Langsa. FKUSU. http://repository.usu.ac.id/handle/1234567 89/31622 (Diakses pada tanggal 22 Maret 2015).

Sanders, Cheryl E \& Gary D. Phye. 2003. Bullying (Implications or The Classroom). United States Of America: Elsevier Academic Press.

Saragih,WR. 2011. Peningkatan Kepedulian terhadap Pemberdayaan Tunagrahita. www.kemsos.go.id (Diakses pada 8 Juni 2015).

Shabo, FH. 2011. Psychososial Impacts of Mentally Retarded Children on Parents In Sudan. Journal of Medical Sciences, Vol.6 (1).

Somantri, S. 2007. Psikologi Anak Luar Biasa. Bandung: Refika Aditama.

Soetjiningsih. 2014. Tumbuh Kembang Anak. Jakarta: EGC. 